136 BOOK REVIEWS

letters to Rho; Panormita's fawning De effigie solis (to Filippo Maria Visconti); and Rho's "Words We Ought to Use Only to Execrate Vice," which is, in effect, a glossary of Latin obscenities. Some of the selections, while they may not seem at first related to Rho's invectives, serve to provide a broader background picture of the Milanese court's politics and pretensions. Thus they help paint what amounts to an unflattering self-portrait of the man Rho: prolix in his display of erudition, carping, envious, defensive, and, in his tireless catalogue of sexual vices, especially sodomy (a charge leveled often against Panormita), highly prurient.

Rutherford provides an accurate, if at times infelicitous (e.g., "wise guy" for homo prudens), English translation, with critical apparatus and extensive annotation, though he leaves the obscene invectives and Panormita's De effigie solis untranslated and without explanatory notes, thus closing them off to readers without Latin. This is a pity, since those portions would be of great interest to scholars in English and the Romance languages who work on such genres as the fabliau and the broadside. This is a book that will be of value chiefly to classicists interested in reception studies, particularly the Renaissance revival of classical invective as a political tool.

EUgene o'Connor, The Ohio State University Press

\title{
Matthew Reynolds
}

Godly Reformers and their Opponents in Early Modern England: Religion

in Norwich c. 156o-1643

Woodbridge: Boydell Press, 2005. Pp. xvi, 310.

Early modern Norwich has long been regarded as one of the urban hotbeds of radical Puritanism. Situated in what A. G. Dickens termed "the heartland of the English Reformation," Norwich has been described by Patrick Collinson as "a self-contained East Anglian Geneva." As Matthew Reynolds explains, this radical identity has been cultivated with pride by the citizenry of Norwich and a "regional religious mythology" has developed. Reynolds does not doubt that extreme Protestantism thrived in Norwich: he simply suggests that other religious sensibilities coexisted alongside it. Throughout the period, internecine squabbles raged among the city's clerical and political elites. "It is striking how contested the Reformation became within the city," Reynolds concludes: "it is inadequate to gloss over early modern Norwich as a puritan citadel."

Reynolds identifies four key stages in the city's religious development. During the first decades of Elizabeth's reign, under the episcopate of John Parkhurst, sig- 
nificant strides were made towards the establishment of a self-styled godly commonwealth. The encouragement of a rigorous, Calvinistic religious ethos was accompanied by social reforms, including an attempt to deal with the city's spiralling levels of poverty. Charismatic preachers like John More flooded in, and clerics played a significant role in the formulation of all aspects of the city's governance. Reynolds rejects the notion, suggested by Muriel McClendon, that these years saw the emergence of de facto toleration in the city-a by-product, in McClendon's analysis, of efforts to achieve local consensus when fending off the intrusions of a centralising Tudor state. On the contrary, Reynolds concludes, confessional antagonism was extremely pronounced.

Reynolds next turns to a significant reversal in godly fortunes. Always suspicious of pockets of radical Protestantism, the Elizabethan regime dispatched Edmund Freke to the city in November 1575. The new bishop set about suppressing prophesyings and pursued an uncompromising policy whereby clerics were expected to offer full conformity to the rites and ceremonies prescribed by the Book of Common Prayer. This strategy continued under Freake's successor, Edmund Scambler, and the emergence of separatist movements—notably Brownism—only heightened the authorities' determination to confront radical tendencies. Reynolds does make the point, however, that even after Browne's flight to Middelburg in 1582, a separatist tradition survived in Norwich.

The early years of James I's reign, Reynolds continues, were relatively peaceful, although stubborn religious tensions continued to simmer. With the arrival of a determined anti-Calvinist party within the Stuart church, these tensions yielded bitter and prolonged conflict. When Samuel Harsnett took up his position as bishop in 1619 he immediately launched a campaign against excessive preaching. He curtailed Sunday morning services and insisted (to the horror of many local consciences) that women being churched should wear a veil. Sectors of an outraged populace went so far as petitioning Parliament to bring Harsnett to book. Reynolds believes that Harsnett's prickly personality goes a long way towards explaining why matters reached such a pitch.

His successor, Francis White, was more conciliatory, but this did not prevent rancorous theological arguments from breaking out. In 1633-1634, for instance, a bitter six-month dispute raged between William Bridge and John Chappell in spite of governmental decrees that forbade the public discussion of predestinarian themes. With the arrival of Matthew Wren in 1635-a man often reckoned more Laudian than Laud-things were always likely to become a good deal more fractious. Wren's altar policy and his campaign to beautify the diocese's churches provoked 
138 BOOK REVIEWS

much protest - even a riot in Ipswich — and during the late 1630 s numerous people felt obliged to seek exile in Holland and the American colonies. This latter group, Reynolds adds, were manifestly motivated by religious disaffection and serve to dent recent attempts to stress the material motivations for exodus to the Americas. In spite of such religious dissent, however, Reynolds shows that not everyone in Norwich sided against Wren. In a parish like St Gregory's a beautification program similar to Wren's long predated his arrival. This mixed response is, Reynolds argues, a prime demonstration of the city's diverse religious attitudes. In his final sections, Reynolds traces how the years leading up to the Civil War saw a godly faction gain almost total control of the city's affairs, although he is careful to note that new divisions - between those of Independent and Presbyterian sympathies-began to develop.

There is much to commend here. Reynolds's use of Norwich's rich archival deposits is exemplary and brings the rivalries and personalities of the period vividly to life. He succeeds in portraying the city's multifaceted religious landscape and his point about particular, local circumstances determining the city's response to Reformation is well-made. When considering those who gave a positive response to Laudian reforms, for instance, he looks to specific, idiosyncratic motivations rather than relying too heavily on generalised explanatory models, such as the positive role played by the "unbroken Catholic continuum" (19) represented by Alexandra Walsham's Church Papists or Christopher Haigh's parish Anglicans.

There are some unusual suggestions, however. The most unsatisfactory concerns alderman Thomas Whalle, whom Reynolds portrays as a crypto-papist for no good reason. Having recusant relations and voicing disdain for foreign Protestant refugees might make the historian suspicious, but without clinching evidence it is premature to claim Whalle as a Catholic-in-disguise. A final point must also be made about Reynolds's approach to criticising his fellow scholars. Criticism is fine-it is vital-but there are different ways of voicing dissent. John Evans' reassessment of the number of ministers forced out of office by Matthew Wren is described as "rather lame." When Kevin Sharpe reassesses Wren's policies, he does so "perversely." Julian Davis' analysis of Wren's role in the Caroline Church is "offbeat." Muriel McClendon's whole account of early modern Norwich is apparently "insipid." Some of this comes perilously close to bad manners and it tarnishes what is an important contribution to our understanding of local responses to the challenges of the English Reformation.

JONATHAN Wright, Hartlepool, United Kingdom 